\title{
Interaction Effects between Organic Fertilizers and Biofertilizers on the Growth of Stevia rebaudiana Bertoni
}

\author{
Mónica Guadalupe Lozano-Contreras ${ }^{1 *}$, Genovevo Ramírez-Jaramillo² ${ }^{2}$, Jorge H. Ramírez-Silva² \\ ${ }^{1}$ Campo Experimental Mocochá del Instituto Nacional de Investigaciones Forestales, Agrícolas y Pecuarias (INIFAP), Mocochá, \\ Yucatán, México \\ ${ }^{2}$ Centro de Investigación Regional Sureste del Instituto Nacional de Investigaciones Forestales, Agrícolas y Pecuarias (INIFAP), \\ Mérida, Yucatán, México \\ Email: lozano.monica@inifap.gob.mx
}

How to cite this paper: Lozano-Contreras, M.G., Ramírez-Jaramillo, G. and RamírezSilva, J.H. (2021) Interaction Effects between Organic Fertilizers and Biofertilizers on the Growth of Stevia rebaudiana Bertoni. Open Access Library Journal, 8: e8065.

https://doi.org/10.4236/oalib.1108065

Received: October 11, 2021

Accepted: November 12, 2021

Published: November 15, 2021

Copyright () 2021 by author(s) and Open Access Library Inc.

This work is licensed under the Creative Commons Attribution International License (CC BY 4.0).

http://creativecommons.org/licenses/by/4.0/

\begin{abstract}
In the last decade Stevia rebaudiana, has become one of the most demanded crops in the market dedicated to health care and food. However, the main consuming countries, from Asia and Europe, are constantly demanding organic products. Therefore, the purpose of this study was to evaluate the effect of organic fertilizers in combination with biofertilizers in the growth of Stevia. A randomized block design with divided plots (large and small) and three replications were used. In the large plots, the cuttings of stevia were inoculated with 1) Rhizophagus intraradices fungus (Rhiz); 2) A mixture of bacterias Bacillusspp. (Bacl) and Azospirillum brasilense (Azo); 3) Trichoderma spp. fungus (Trch); 4) A treatment with no inoculant (c). These inoculation treatments were combined, in the smaller plots with three sources of organic fertilizers named: 1) Sheep manure (Shim); 2) Bocashi (Bcsh); 3) chicken manure $(\mathrm{Chm})$; 4) A treatment with any organic fertilizer. The plot with no inoculants nor organic fertilizers was the Absolute Control (Ac). There was a positive relationship between organic fertilizers and biofertilizers in the growth of Stevia. The highest yield corresponded to the Rhiz + Bcsh with $450.00 \mathrm{~kg} \cdot \mathrm{ha}^{-1}$ followed by Rhiz + Shim, and Trch + Chmboth with $410.00 \mathrm{~kg} \cdot \mathrm{ha}^{-1}$. The treatment with the lowest yield was the Ac with 120.00 $\mathrm{kg} \cdot \mathrm{ha}^{-1}$.
\end{abstract}

\section{Subject Areas}

Agricultural Engineering 


\section{Keywords}

Natural Sweetener, Inoculation, Biofertilizers

\section{Introduction}

The management of organic fertilizers has traditionally been used by farmers in small areas of land, incorporating organic materials (manure, household fruit and vegetable waste) into the agrosystems [1]. The application of organic fertilizers dates back to the times of the Aztecs and Mayans, who used fish as a source of phosphorus [2]. The Aztecs intensely used the so-called chinampas; a kind of rafts covered with underground mud to grow flowers and vegetables in swampy soils with high humidity and abundant organic fertilizers [3]. The soft mud, as silt, was extracted at a maximum depth of three meters from the bottom of the lakes and placed on the upper part of the platforms. Water lilies and other floating organic materials were also used [3].

While time was passed by the population growth in an accelerated way and in consequence there was a need to intensively produce agricultural crops so the ancient production systems falled into disuse. However, intensive agricultural activities to the detriment of organic matter reserves and reduce soil fertility [4]. In recent years, at the global level, the incorporation of fertilizers and organic manures (manure and compost) for soil bioremediation in agricultural soils has regained importance [5] [6] [7]. Organic fertilizers can satisfy the nutrient demand of crops while significantly reducing the use of chemical fertilizers and improving the characteristics of the vegetables to be consumed [8]. Furthermore, organic fertilizers are able to improve the soils attribute that have been deteriorated by the excessive use of agrochemical and over-exploitation [1].

On the other hand, biofertilizers are other components that can contribute to improving soil deterioration and stimulating crop growth and productivity [9]. They are products that contain microorganisms, which when inoculated can live associated or in symbiosis with plants to improve nutrition [10]. These micro-organisms are found naturally in the soil and comprise various groups [11]. The bacterias commonly used in agriculture are of the genus Rhizobium and Azospirillum [12]. The fungus arbuscular mycorrhiza has been reported as a microorganism capable to stimulate vegetative growth when soil nutrients such as $\mathrm{N}, \mathrm{P}$ and $\mathrm{K}$ are absorbed and introduced into the plants [13]. The growing interest in developing agriculture with low use of agrochemicals is based on the awareness of taking care the environment and the high cost and low efficiency of inorganic fertilizers so farmers are seeking new alternatives such as the use of biological and organic fertilizers [14]. In the particular case of Stevia rebaudiana (Bertoni), it is important to achieve a safe natural production due to the fact that leaves are the directly consume product. The steviosides and rebaudiosides (steviol glycosides), found in the leaves, are the most important chemical compo- 
nents of stevia and are 200 to 300 times sweeter than common cane sugar (containing sucrose) [15] [16] [17]. They comprise nine glycosides (1) rebaudioside A, (2) steviolboside, (3) stevioside, (4) rubusoside, (5) rebaudioside $B,(6)$ rebaudioside $\mathrm{C}$, (7) rebaudioside $\mathrm{D},(8)$ rebaudioside $\mathrm{F}$ and (9) dulcoside $\mathrm{A}$, which can be determined by high-performance liquid chromatography (HPLC) [18]. Due to the foregoing, the production and management of stevia must be carried out by applying technologies that are more friendly to the environment and to human health.

A possible way to cope with the problem is by using biofertilizers such as arbuscular mycorrhizal fungi [19] and organic fertilizers. The organic products can supply micro and macronutrients to the crops and have the advantage of improving the soil structure for good aeration and moisture retention. In this way, soil erosion can be diminished and soil temperature is regulated [20]. Therefore, the purpose of this study was to evaluate the effect of organic fertilizers, in combination with biofertilizers, on the growth of $S$. rebaudiana.

\section{Materials and Methods}

This work was carried out under field and irrigation conditions in a red soil ( $L u$ visol) at the Uxmal Experimental Station belonging to the National Institute of Forestry, Agricultural and Livestock Research (INIFAP). It is located in the municipality of Muna, Yucatán, Mexico at 20²9'08.1 North latitude and 89 $24^{\prime} 39$ West longitude with an altitude of 50 meters above sea level. The climate is of the Aw type, which is the driest of the warm subhumid ones with summer rains, average annual precipitation and temperature of $900 \mathrm{~mm} 25^{\circ} \mathrm{C}$ respectively [21].

\section{Establishment of the Experiment}

The experiment was established on a loamy-silty texture soil with $\mathrm{pH}$ of 7.8, electrical conductivity (EC) of $1.1 \mathrm{dS} \cdot \mathrm{m}^{-1}$, organic matter (OM) of $4.8 \%$, with $0.13 \%$ nitrogen, $43.4 \mathrm{mg} \cdot \mathrm{kg}^{-1}$ of phosphorus, $229 \mathrm{mg} \cdot \mathrm{kg}^{-1}$ of available potassium. A complete random block design, with three replications, was used in splitted large and small plots. In the large plots, biofertilizers were applied to high quality selected cuttings of Stevia rebaudiana Bertoni (Creole variety) coming from six months old plants.

The cuttings were inoculated with: 1) Rhizophagus intraradices (Rhiz) at 1 spore $\mathrm{mL}^{-1}$ (INIFAP ${ }^{\mathrm{MR}}$ Mycorrhiza brand); 2) Mixture of Bacillus spp. (Bacl) and Azospirillum brasilense (Azo) $\left(1 \times 10^{8} \mathrm{cfu} \cdot \mathrm{mL}^{-1}\right)$ (BactoCROP $\left.\left.{ }^{\mathrm{MR}}\right) ; 3\right)$ Trichoderma spp. (Trch) at $1 \times 10^{8} \mathrm{cfu} \cdot \mathrm{mL}^{-1}$ (INI04-INIFAP brand); 4) a treatment control with just the corresponding biofertilizer was considered to see the effect of the inoculants alone. The amount of $70 \mathrm{~g} \cdot \mathrm{L}^{-1}$ of inoculants, in solid forms, were diluted in tap water and stirred themuntil having a homogeneous solution. The inoculation was carried out according to the methodology proposed by Lozano and Ramírez [22], consisting of soaking the cuttings of stevia for one minute in the solution before sowing. 
In the smaller plots, three types of organic fertilizers were applied: 1) Sheep manure (Shim) (15 thha $\left.{ }^{-1}\right)$; 2) Bocashi (Bcsh) (15 tha $\left.{ }^{-1}\right)$; 3) Chicken manure (Chim) (15 tha $\left.{ }^{-1}\right)$; 4) Unfertilized treatment was considered. In Table 1 the chemical analysis of each organic fertilizers are noted.

All inoculation treatments combined with the organic fertilizers, including their corresponding controls, made up 16 treatments. The Absolute Control (Ac) was the treatment with no organic fertilizer nor inoculant.

Prior to the transplant, the organic fertilizers were spread manually in the small plots. The transplant was carried out on june 2016 at a population density of one hundred thousand plantsper hectare. The plants were pruned (formation pruning) 15 days after transpantation. The first and unique harvest was done two months after transplanting.

Drip irrigation was used with 1500 tape gauge, emitters every $30 \mathrm{~cm}$ with a water flow rate of $1.5 \mathrm{~L} \cdot \mathrm{h}^{-1}$. The hoses were covered with100 $\mu$ thick silver/blackpadd plastic.

\section{Measured Variables for Stevia under Field Conditions}

The growth of 10 representative stevia plants, from each plot, were evaluated measuring the next parameters: 1) Height of the plant measured from the base of the stem to the last foliar apex; 2) Production and distribution of dry biomass (stem and leaves) dried in a forced air oven at $65^{\circ} \mathrm{C}$ until constant weight; 3) Total dry leaf yield obtained at 65 days after transplantation. All parameters were submitted to an Analysis of Variance (ANOVA) and to a mean comparison test

Table 1. Chemical analysis of organic fertilizers used in the experiment.

\begin{tabular}{|c|c|c|c|}
\hline Soil attributes & Sheep manure & Bocashi & Chicken manure \\
\hline $\mathrm{pH}$ & 7.64 & 7.36 & 7.50 \\
\hline $\mathrm{EC}\left(\mathrm{mS} / \mathrm{cm}^{-1}\right)$ & 38.50 & 11.93 & 20.40 \\
\hline $\mathrm{OM}(\%)$ & 32.16 & 9.78 & 30.15 \\
\hline $\mathrm{N}-\mathrm{NO}_{3}\left(\mathrm{mg} \cdot \mathrm{Kg}^{-1}\right)$ & 1,728 & 408 & 1,620 \\
\hline $\mathrm{PO}_{4}-\mathrm{P}\left(\mathrm{mg} \cdot \mathrm{Kg}^{-1}\right)$ & 390 & 115 & 870 \\
\hline $\mathrm{S}-\mathrm{SO}_{4}^{2-} \quad\left(\mathrm{mg} \cdot \mathrm{Kg}^{-1}\right)$ & 68.33 & 20.00 & 436.67 \\
\hline $\mathrm{Na}^{+}(\mathrm{Meq} / 100 \mathrm{~g})$ & 10.43 & 3.13 & 8.13 \\
\hline $\mathrm{K}^{+}(\mathrm{Meq} / 100 \mathrm{~g})$ & 28.13 & 9.95 & 15.60 \\
\hline $\mathrm{Ca}^{2+}(\mathrm{Meq} / 100 \mathrm{~g})$ & 30.00 & 33.50 & 23.00 \\
\hline $\mathrm{Mg}^{2+}(\mathrm{Meq} / 100 \mathrm{~g})$ & 18.63 & 9.00 & 16.08 \\
\hline CEC (meq/100g) & 87.20 & 55.58 & 62.81 \\
\hline
\end{tabular}

Note: $\mathrm{pH}=$ Hidrogen ions activity measuring grade of acidity or alkalinity, C.E. $=$ electrical conductivity, $\mathrm{OM}=$ organic matter, $\mathrm{N}^{-\mathrm{NO}_{3}^{-}}=$nitric nitrogen (Brusin), $\mathrm{PO}_{4}-\mathrm{P}=$ phosphorus from phosphates (Bray method), $\mathrm{S}_{-} \mathrm{SO}_{4}^{2-}=$ sulfur from sulfates, $\mathrm{Na}^{+}=$sodium, $\mathrm{K}^{+}=$potassium, $\mathrm{Ca}^{2+}=$ calcium, $\mathrm{Mg}^{2+}=$ magnesium, $\mathrm{CEC}=$ Cation Exchange Capacity (by Ammonium Acetate $1 \mathrm{~N} \mathrm{pH} \mathrm{7).}$ 
(Tukey, $\mathrm{p} \leq$ 0.05) using the SAS statistical package version 9.2 [23].

\section{Results and Discussion}

\subsection{Plant Height as Related to Organic Fertilizers and Biofertilizers}

Statistically significant differences ( $\mathrm{p} \leq 0.05)$ were observed between treatments inoculated with Rhiz plus organic manures. The combination of Shim plus Rhiz showed the maximum height $(15.14 \mathrm{~cm})$. Shim with no inoculants had the lowest one $(11.38 \mathrm{~cm})$ as it is shown in Table 2. Biofertilizers showed a stimulating

Table 2. Hight (cm), and weight (g/plant) of dry leaves and stems of Stevia with biofertilizers and/or organic ferilizers. 65 days after transplantation.

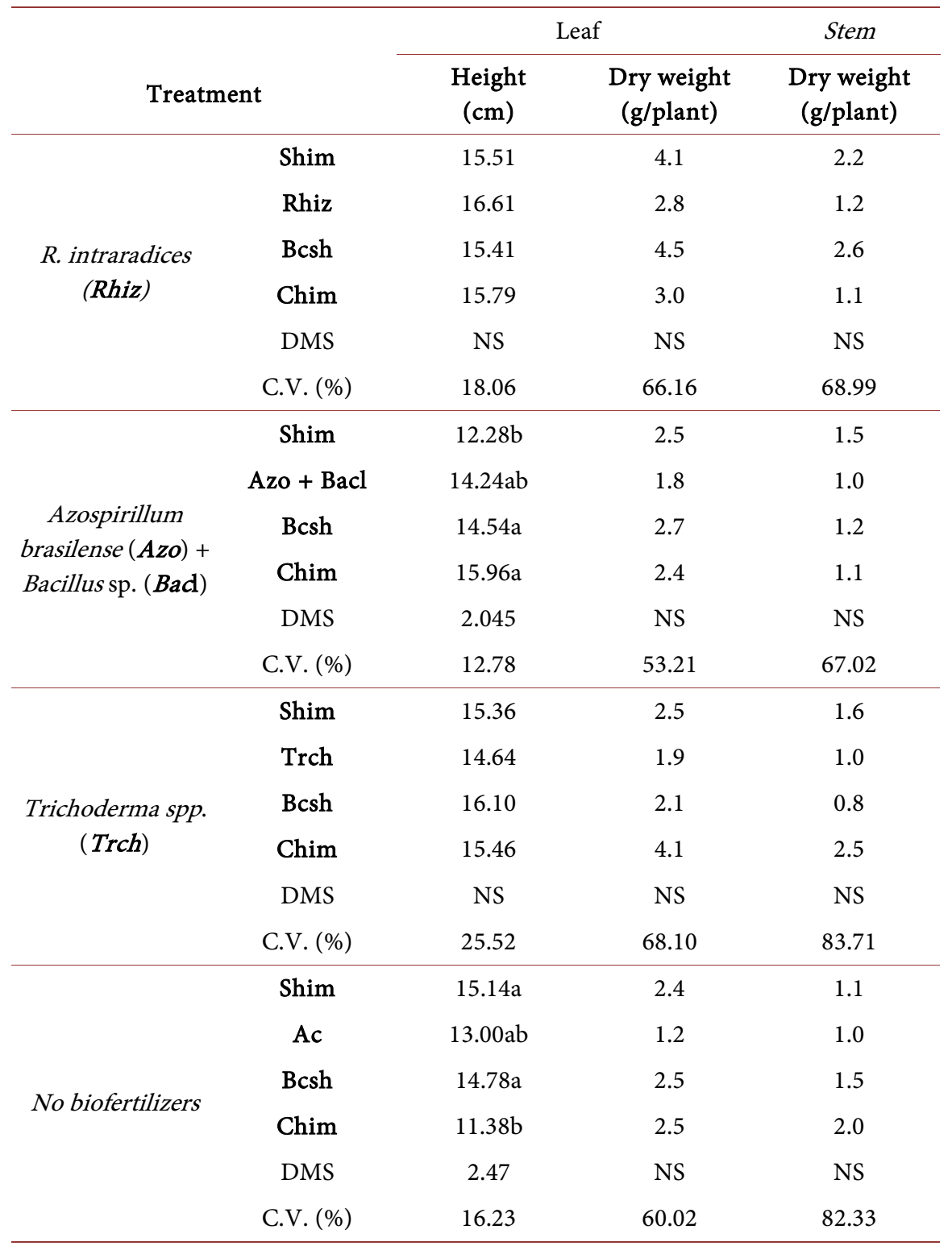

Note: Values with the same letters are atatistically equals according to Tukey Test ( $\mathrm{p}<$ 0.05). C.V. = Coefficient of Variation. 
effect on plant growth.

The Rhiz alone, obtained a higher height compared to non-inoculated plants. This was to be expected since Arbuscular mycorrhizal fungi (AMF) form abundant external hyphae as an extention of roots. In this way, water absorption and nutrient translocation (mainly phosphorus) is enhanced, stimulating the plant growth [24]; this may also be related to a stimulating effect of phytohormones released by the AMF [25].

When organic fertilizers were inoculated with the mixture of Azo and Bacl significant statistical differences ( $\mathrm{p} \leq 0.05)$ were observed. The interactions with Chim registered the maximum height with $15.96 \mathrm{~cm}$ (Table 2), followed by Bcsh with $14.54 \mathrm{~cm}$. When Azo plus Bacl were applied with no organic fertilizers showed a hight of $14.24 \mathrm{~cm}$. The lowest height was with Shim alone with $12.28 \mathrm{~cm}$ high.

Certain species of bacteria such as Pseudomonas or Bacillus can exert a direct action by stimulating plant growth and, at the same time, antagonizing pathogens and/or stimulating plant defenses [26]. Once into the roots, the AzospirilIum bacterium is capable to convert gaseous nitrogen into available nutrimental forms in order to estimulate better plant growth [27]. It is highly possible that bacterium stopped to produce inorganic nitrogen (from the air nitrogen) as long as organic fertilizers was applied. This effect was mainly appreciated when the hight $(14.24 \mathrm{~cm})$ with Azo + Bacl + Shim was compared to the Shim alone $(12.28 \mathrm{~cm})$.

The plants inoculated with Trch and mixed with Bcsh $(16.10 \mathrm{~cm})$, Chim $(15.46 \mathrm{~cm})$ and Shim $(15.36 \mathrm{~cm})$, had the highest height (Table 2) as compared to Trch alone $(14.64 \mathrm{~cm})$. The effect of Trichoderma in promoting plant growth is widely known; this is related to the production of indoleacetic acid (IAA), the ability to solubilize phosphates and produce compounds called siderophores capable to improve nutrients availability [28]. However, the beneficial effect of Trichoderma on stevia growth has been studied very little [29].

Studies such as those of Garcés [30], mentioned that both height and green matter production of alfalfa increased at the addition of solid organic fertilizer enriched with Trichoderma. Organic fertilizers have high content of growth stimulators such as free amino acids.

In relation to the effect of organic fertilizers alone, with no biofertilizers, significant statistical differences ( $\mathrm{p} \leq 0.05$ ) were observed between treatments. The Shim and Bcsh treatments showed the highest plant height, with 15.14 and 14.78 $\mathrm{cm}$ respectively, followed by the Ac with $13.0 \mathrm{~cm}$ and Chim with $11.38 \mathrm{~cm}$ (Table 2).

Cegarra et al. [31] reported that organic fertilizers have high mineral nitrogen content and significant amounts of other nutritive elements for plants. Depending on the applied level, they can increase the content of soil organic matter, improve moisture retention and regulate the $\mathrm{pH}$ [32] [33]. They can increase potassium [34], calcium and magnesium [35] [36] availability in the soil. 


\subsection{Weight of Dry Leaves (g/plant) as Related to Treatments}

No statistical differences $(\mathrm{p} \leq 0.05)$ were found between yields of dry leaves when stevia was trated with bioinoculants and organic fertilizers (Table 2). The highest weight of dry leaves was obtained with Rhiz combined with Bcsh (4.5 g/plant) followed by Rhiz plus Shim, and Trch plus Chim with $4.1 \mathrm{~g} / \mathrm{plant}$ each one. The lowest weight (1.2 g/plant) was found when plants were not inoculated and organic manures not applied (Ac). Regardless of the manures treatments, the best plant response was observed when $\mathrm{Rhz}$ was inoculated. This favorable effect can be explained, in part, to better absorption of unmobile nutrients from the soil such as phosphorus, zinc and copper when roots, due to Rhz colonization can explore more soil volume (length and depth) [37].

\subsection{Wieight of Dry Stems (g/plant) According to Treatments}

The stem is of great importance for the survival and growth of stevia. The cuttings are produced from the stems, so plants with great potential for homogeneous production can be selected and preserved. The results showed that the treatments: Rhiz + Bcsh (2.6 g/plant), Trch + Chim (2.5 g/plant), Rhiz + Shim ( $2.2 \mathrm{~g} /$ plant) and Chim alone had the highest stem weight (Table 2). The other treatments, with the lowest stem weight, ranged from 0.8 to $1.5 \mathrm{~g} / \mathrm{plant}$. Therefore, the use of different organic fertilizers and biofertilizers, used in this work, has an unequal impact on the final weight of the stem. The previous findings are in disagreement with the normal expectation that both endo-mycorrhizal fungi and $\mathrm{N}$-fixing bacteria are capable, per se, of stimulating plant growth and reproduction of annual [38] and perennials crops [39] under nursery conditions.

\subsection{Yield of Dried Leaves of Stevia $\left(\mathrm{kg} \cdot \mathrm{ha}^{-1}\right)$}

The ANOVA of dry leaves $\left(\mathrm{Kg}_{\mathrm{ha}}{ }^{-1}\right)$ at the first cut (65 days after transplanting) showed statistical differences between treatments. Figures 1(a) (d) are shown the yields obtained with biofertilizers and/or organic biofertilizers. Statistical analysis detected significant differences between treatments at first cut. The highest yield corresponded to Rhiz + Bcsh with $450.00 \mathrm{~kg} \cdot \mathrm{ha}^{-1}$, followed by Rhiz

+ Shim and Trch + Chim with $410.00 \mathrm{~kg} \cdot \mathrm{ha}^{-1}$ both. The treatment with the lowest yield was the Absolute Control (Ac) with $120.00 \mathrm{~kg} \cdot \mathrm{ha}^{-1}$.

The combination of Trch + Shim and Bcsh showed low yields with 250.00 and $210.00 \mathrm{~kg} \cdot \mathrm{ha}^{-1}$ respectively (Figure $1(\mathrm{c})$ ). This could be related to some factors such as: 1) The natural mechanism of the biological product, with a chemical substance which needs suitable environment to work properly [40], Native strains extracted from local soilss would be more functional due to its biological adaptation to the environment [41]; 2) The low yield of Trch, is also related to the principle of competitive exclusion, also known as Gause's law; suggesting that two species competing for the same resources cannot coexist if other ecological factors are constant [42].

On the other hand, the yields with organic fertizers (Shim, Bcsh, Chim) did 


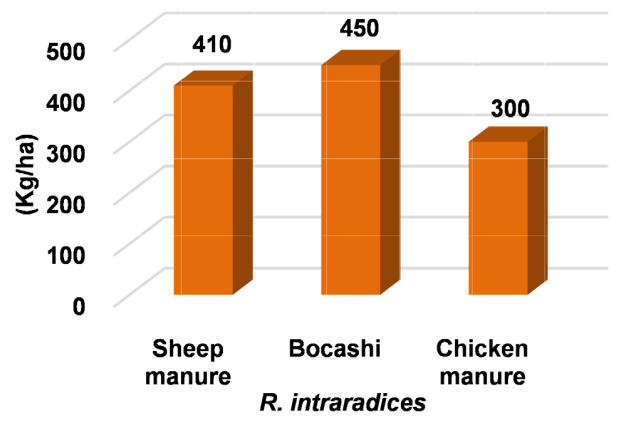

(a)

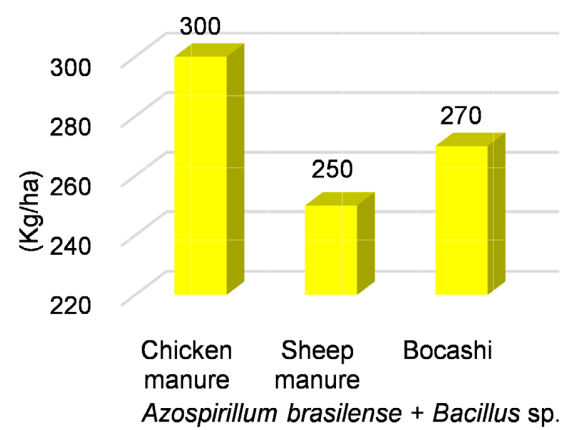

(b)

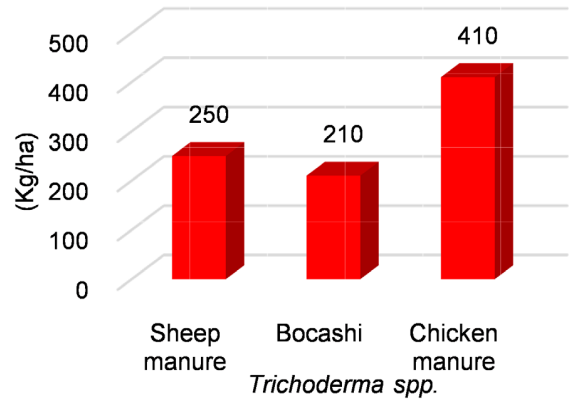

(c)

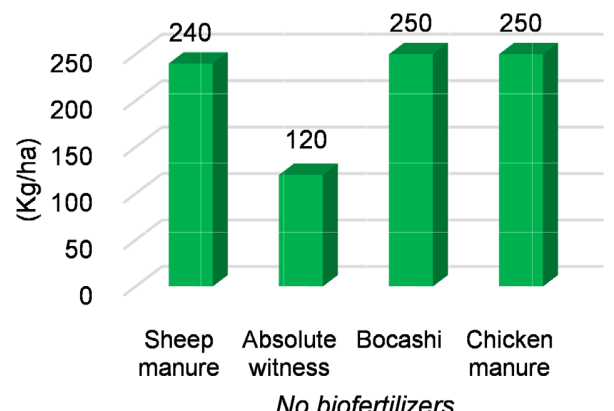

(d)

Figures 1. (a) R. intraradices (Rhiz); (b) Azospirillum brasilense (Azo) + Bacillus sp. (Bacl); (c) Trichoderma spp. (Trch); (d) No biofertilizers. Interaction effects between Organic Fertilizers and Biofertilizers on the yield of stevia dry leaves $\left(\mathrm{kg} \cdot \mathrm{ha}^{-1}\right) 65$ days after transplanting under field conditions. 
not show important differences when inoculated with the mixture of Rhiz + Bacl (Figure 1(a)); and the yields, ranging from 250.00 to $300.00 \mathrm{~kg} \cdot \mathrm{ha}^{-1}$ is similarto those observed without inoculation (240.00 to $250.00 \mathrm{~kg} \cdot \mathrm{ha}^{-1}$ ). Although in this work the advantage of using Plant Growth Promoting Rhizobacteria (PGPR) was not reflected, there are reports suggesting the potentiality they have to enhance the contents of lycopene, total sugars and ascorbic acid in fruits [43], The PGPR are able to increase the number of fruits per plant and their quality when bacteria are capable to synthesize phytohormones such as cytokinins and Indole Acetic Acid (IAA). They have the advantage of fixing gaseous nitrogen, solubilizing phosphorus and are capable to inhibit phytopathogenic microorganisms [44].

\section{Conclusion}

The use of organic fertilizers combined with biofertilizers improved the growth of Stevia rebaudiana. The use of Rhizophagus intraradices (Rhiz) being the best biofertilizer to be combined with the organic fertilizers (Shim, Bcsh, Chim) since the yields of dry leaves ranged from 300.00 to $450.00 \mathrm{~kg} \cdot \mathrm{ha}^{-1}$ while the $\mathrm{Ab}$ solut Control (Ac) had just $120.00 \mathrm{~kg} \cdot \mathrm{ha}^{-1}$. It seems that both biofertilizers and organic fertilizers, either alone or in combination can induce better production of Stevia rebaudiana.

\section{Acknowledgements}

We thank the National Institute of Forestry, Agricultural and Livestock Research (INIFAP), for financing this work as part of the project called: Proyecto de Investigación y Transferencia de Tecnologíasobre el Empleo de Biofertilizantes y Abonos Orgánicos en la Agricultura (Research and Technology Transfer Project on the Use of Biofertilizers and Organic Fertilizers in Agriculture). Project number “13451632421".

\section{Conflicts of Interest}

The authors declare no conflicts of interest regarding the publication of this paper.

\section{References}

[1] Nieto-Garibay, A., Murillo-Amador, B., Troyo-Diéguez, E., Larrinaga-Mayoral, J.Á. and García-Hernández, J.L. (2002) El uso de compostas como alternative ecológica para la producción sostenible del chile (Capsicum annuum L.) en zonas áridas. Interciencia, 27, 417-421. https://www.redalyc.org/pdf/339/33907106.pdf

[2] Martinez, C.C. (2003) Abonos Orgánicos: Origen, Usos y Aplicación. Secretaría de Desarrollo Social del Gobierno del Estado de Chiapas. Dirección de Promoción Social. Chiapas, México, 14 p.

[3] Hernández Garciadiego, R. and Herrerías Guerra, G. (1998) Amaranto: Historia y Promesa. Tehuacán: Horizonte del Tiempo. Vol. 1 Patrimonio Histórico de Tehuacán A. C, México, 529 p. http://www.alternativas.org.mx/Amaranto.pdf 
[4] Álvarez Solís, J.D., Ferrera Cerrato, R. and Etchevers Barra, J.D. (2000) Actividad microbiana en tepetate con incorporación de residues orgánicos. Agrociencia, 34, 523-532. https://www.redalyc.org/articulo.oa?id=30234501

[5] Pansu, M., Sallih, Z. and Bottner, P. (1998) Modelling of Soil Nitrogen Forms after Organic Amendments under Controlled Conditions. Soil Biology and Biochemistry, 30, 19-29. https://doi.org/10.1016/S0038-0717(97)00087-4 https://www.sciencedirect.com/science/article/abs/pii/S0038071797000874

[6] Ruíz, F.J.F. (1996) Los fertilizantes y la fertilizaciónorgánica bajo la óptica de un sistema de producción orgánica. En Altamirano, Z. and Arózqueta, C., Eds., Memorias Primer Foro Nacional sobre Agricultura Orgánica, Universidad Autónoma Metropolitana, Unidad Xochimilco, México, DF, 23-47.

[7] Abdel Magid, H.M., Sabrah, R.E.A., El Nadi, A.R.H., Abdel-Aal, S.I. and Rabic, R.K. (1994) Kinetics of Biodegradation Bates of Chicken Manure and Municipal Refuse in a Sandy Soil. Journal of Arid Environments, 28, 163-171.

https://doi.org/10.1016/S0140-1963(05)80047-3

[8] Rodríguez Dimas, N., Cano Ríos, P., Figueroa Viramontes, U., Favela Chávez, E., Moreno Reséndez, A., Márquez Hernández, C., Ochoa Martínez, E. and Preciado Rangel, P. (2009) Uso de abonos orgánicos en la producción de tomate en invernadero. Terra Latinoamericana, 27, 319-327.

https://www.redalyc.org/pdf/573/57313040006.pdf https://www.researchgate.net/profile/Candido-Marquez/publication/264274248_Us o_de_abonos_organicos_en_la_produccion_de_tomate_en_invernadero/links/53d6 84d90cf228d363ea5d90/Uso-de-abonos-organicos-en-la-produccion-de-tomate-eninvernadero.pdf

[9] Rueda, P.E.O., Murillo, A.B., García, H.J.L., Barrón, H.J.M., Preciado, R.P. and Tarazón, H.M.A. (2009) Las bacterias promotoras del crecimiento vegetal como biofertilizantes en ambientes árido salinos. In: Castillo, I.O., Salazar, E., Fortis, M., Trejo, H.I., Vázquez, C., López, J.D., Figueroa, R., Zúñiga, R., Preciado, P. and Chavarría, J.A., Eds., agricultura orgánica, Comisión Nacional de la Ciencia del Suelo y CONACYT. Gómez Palacio, México, 259-272.

[10] Kevin Vessey, J. (2003) Plant Growth Promoting Rhizobacteria as Biofertilizers. Plant and Soil, 255, 571-586. https://doi.org/10.1023/A:1026037216893

[11] Caballero-Mellado, J., Carcaño-Montiel, M.G. and Mascarua-Esparza, M.A. (1992) Field Inoculation of Wheat (Triticum aestivum) with Azospirillum brasilense under Temperate Climate. Symbiosis, 13, 243-253. https://dalspace.library.dal.ca/bitstream/handle/10222/77357/VOLUME\%2013-NU MBERS\%201,2,3-1992-PAGE\%20243.pdf?sequence=1

[12] Caballero-Mellado, J., Onofre-Lemus, J., Estrada-de los Santos, P. and MartínezAguilar, L. (2007) The Tomato Rhizosphere, an Environment Rich in Nitrogen fixing burkholderia Species with Capabilities of Interest for Agriculture and Bioremediation. Applied and Environmental Microbiology, 73, 5308-5319. https://doi.org/10.1128/AEM.00324-07

[13] Mendoza, H.A. and Cruz, H.M.A. (2010) Empleo de Azospirillum Comobiofertilizante. In: Aguado, G.A., Ed., Introducción al uso y manejo de los biofertilizantes en la agricultura. INIFAP-SAGARPA, México, 171-185.

[14] Umesha, S., Divya, M., Prasanna, K.S., Lakshmipathi, R.N. and Sreeramulu, K.R. (2014) Comparative Effect of Organics and Biofertilizers on Growth and Yield of Maize (Zea mays L.). Current Agriculture Research Journal, 2, 55-62.

https://doi.org/10.12944/CARJ.2.1.08 
[15] Geuns, J.M.C, Augustijns, P., Mols, R., Buyse, J.G. and Driessen, B. (2003) Metabolism of Stevioside in Pigs and Intestinal Absorption Characteristics of Stevioside, Rebaudioside A and Steviol. Food and Chemical Toxicology, 41, 1599-1607. https://doi.org/10.1016/S0278-6915(03)00191-1 https://www.sciencedirect.com/science/article/abs/pii/S0278691503001911

[16] Grosso, V., Podetti, J. and Soltermann, A. (2012) Stevia rebaudiana Bertoni. Cuadernillo de Divulgación del Laboratorio de Desarrollo y Vinculacion Tecnologica. Colección vinculación y Educación. Universidad Nacional de Río Cuarto Ruta Nacional. Río Cuarto, Argentina. UniRio Editora, 24 p.

[17] Christaki, E., Bonos, E., Giannenas, I., Karatzia, M.A. and Florou-Paneri, P.C. (2013) Stevia rebaudiana as a Novel Source of Food Additives. Journal of Food and Nutritional Research, 52, 195-202.

[18] Chaturvedula, V.S.P. and Zamora, J. (2014) Reversed-Phase HPLC Analysis of Steviol Glycosides Isolated from Stevia rebaudiana Bertoni. Food and Nutrition Sciences, 5, 1711-1716. https://doi.org/10.4236/fns.2014.517184

[19] Adesemoye, A.O., Torbert, H.A. and Kloepper, J.W. (2009) Plant Growth-Promoting Rhizobacteria Allow Reduced Application Rates of Chemical Fertilizers. Microbial Ecology, 58, 921-929. https://doi.org/10.1007/s00248-009-9531-y

[20] Shintani, M., Leblanc, H. and Tabora, P. (2000) Bokashi, Abono orgánico fermentado; Tecnología Tradicional Adaptada para una Agricultura Sostenible y un Manejo de Desechos Modernos. (1 Ed.). Escuela de Agricultura de la Región Tropical Humedad. San José, Costa Rica, 14-25.

[21] Uribe-Valle, G. and Dzib-Echeverría, R. (2006) Micorriza arbuscular (Glomus intraradices), Azospirillum brasilense y Brassinoesteroide en la producción de maízen el suelo luvisol. Agricultura Técnica en México, 32, 67-76.

https://www.redalyc.org/pdf/608/60832107.pdf

[22] Lozano-Contreras, M.G. and Ramírez-Jaramillo, G. (2015) Enraizamiento de esquejes de estevia con biofertilizantes. Desplegable para productores No. 6, Centro de investigación regional sureste. Campo experimental Mocochá. Mérida, Yucatán.

[23] SAS Institute (2011) The SAS System for Windows. Release 9.2. SAS Inst., Cary.

[24] Daniels-Hylton, K.D.M. and Ahmad, M.H. (1994) Inoculation Response in Kidney Beans (Phaseolus vulgaris L.) to Vesicular-Arbuscular Mycorrhizal Fungi and Rhizobia in Non-Sterilized Soil. Biology and Fertility of Soils, 18, 95-98. https://link.springer.com/article/10.1007/BF00336452

[25] Allen, B.L., Jolley, V.D., Robbins, C W. and Freeborne, L.L. (2001) Fallow versus Wheat Cropping of Unamended and Manure-Amended Soils Related to Mycorrhizal Colonization, Yield and Plant Nutrition of Dry Bean and Sweet Corn. Journal of Plant Nutrition, 24, 921-943. https://doi.org/10.1081/PLN-100103782

[26] Hernández-León, R., Rojas-Solís, D., Contreras-Pérez, M, Orozco-Mosqueda, M.D.C., Macías-Rodríguez, L.I., Reyes-de la Cruz, H., Valencia-Cantero, E. and Santoyo, G. (2015) Characterization of the Antifungal and Plant Growth-Promoting Effects of Diffusible and Volatile Organic Compounds Produced by Pseudomonas fluorescens Strains. Biological Control, 81, 83-92.

https://doi.org/10.1016/j.biocontrol.2014.11.011

[27] Domingues Duarte, C.F., Cecato, U., Trento Biserra, T., Mamédio, D. and Galbeiro, S. (2020) Azospirillum spp. engramíneas y forrajeras. Revisión. Revista mexicana de ciencias pecuarias, 11, 223-240. https://doi.org/10.22319/rmcp.v11i1.4951

[28] Kashyap, P.L., Rai, P., Srivastava, A.K. and Kumar, S. (2017) Trichoderma for Climate Resilient Agriculture. World Journal of Microbiology Biotechnology, 33, Arti- 
cle No. 155. https://doi.org/10.1007/s11274-017-2319-1

[29] Villamarín-Gallegos, D., Oviedo-Pereira, D.G., Evangelista-Lozano, S., SepúlvedaJiménez, G., Molina-Torres, J. and Rodríguez-Monroy. M. (2020) Trichoderma asperellum, an Inoculant for the Production of Steviol Glycosides in Stevia rebaudiana Bertoni Plants Micropropagated in a Temporary Immersion Bioreactor. Revista Mexicana de Ingeniería Química, 19, 1153-1161.

https://doi.org/10.24275/rmiq/Bio947 http://rmiq.org/ojs311/index.php/rmiq/article/view/947/429

[30] Garcés, K.S.R. (2011) Evaluación de diferentes niveles de abono orgánico solido potencializado con Trichoderma en la producción de Medicago sativa (Alfalfa) en la estación experimental Sunshi. Riobamba, Chimborazo, Ecuador, 76 p

[31] Cegarra, J.A., Roig, A.F., Navarro, M.P., Bernal, M., Abad, M., Climent, D. and Aragón, P. (1993) Características, compostaje y uso agrícola de residues sólidosurbanos. In: Warman, P.R. and Taylor, B.R., eds., Memorias Jornadas de Recogidas Selectivasen Origen y Reciclaje, Mundi-Prensa, Córdoba, España, 46-55.

[32] Ouédraogo, E., Mando, A. and Zombré, N.P. (2001) Use of Compost to Improve Soil Properties and Crop Productivity under Low Input Agricultural System in West Africa. Agriculture, Ecosystems \& Environment, 84, 259-266.

https://doi.org/10.1016/S0167-8809(00)00246-2

https://www.sciencedirect.com/science/article/abs/pii/S0167880900002462

[33] Courtney, R.G. and Mullen, G.J. (2008) Soil Quality and Barley Growth as Influenced by the Land Application of Two Compost Types. Bioresource Technology, 99, 2913-2918. https://doi.org/10.1016/j.biortech.2007.06.034

[34] Erhart, E. and Hartl, W. (2003) Mulching with Compost Improves Growth of Blue Spruce in Christmas Tree Plantations. European Journal of Soil Biology, 39, 149-156. https://doi.org/10.1016/S1164-5563(03)00030-X

[35] Jakobsen, S.T. (1996) Leaching of Nutrients from Pots with and without Applied Compost. Resources, Conservation and Recycling, 17, 1-11. https://doi.org/10.1016/0921-3449(96)01069-5

[36] Miyasaka, S.C., Hollyer, J.R. and Kodani, L.S. (2001) Mulch and Compost Effects on Yield and Corm Rots of Taro. Field Crops Research, 71, 101-112. https://doi.org/10.1016/S0378-4290(01)00154-X

[37] Sánchez de la Cruz, R., Díaz-Franco, A., Pecina-Quintero, V., Garza-Cano, I. and Loera-Gallardo, J. (2008) Glomus intraradices y Azospirillum brasilense en trigo bajo dos regímenes de humedaden el suelo. Universidad y Ciencia, 24, 239-245. http://www.scielo.org.mx/pdf/uc/v24n3/v24n3a8.pdf

[38] Aguirre-Medina, J.F. (2006) Biofertilizantes microbianos: Experiencias agronómicas del programa nacional del INIFAP en México. Instituto Nacional de Investigaciones Forestales, Agrícolas y Pecuarias-Centro de Investigaciones Regionales Pacífico Sur-Campo Experimental Rosario Izapa, México.

[39] Aguirre-Medina, Juan F., Mina-Briones, Francisco O., Cadena-Iñiguez, Jorge, DardónZunun, J.D. and Hernández-Sedas, D.A. (2014) Crecimiento de Cedrelao dorata L. Biofertilizada con Rhizophagus intraradices y Azospirillum brasilense en vivero. Revista Chapingo Serie Ciencias Forestales y del Ambiente, 20, 177-183. https://doi.org/10.5154/r.rchscfa.2014.01.001

[40] Harman, G.E. (2000) Myths and Dogmas of Biocontrol. Changes in Perceptions Derived from Research on Trichoderma harzianum T-22. Plant Disease, 84, 377-393. https://doi.org/10.1094/PDIS.2000.84.4.377

[41] Pertot, I., Alaboubette, C., Hinarejos, E. and Franca, S. (2015) Mini Papaer: The Use 
of Microbial Biocontrol Agents against Soil-Borne Diseases. Eip-Agri, Agriculture \& Innovation, Bruselas, Bélgica.

$\underline{\text { http://ec.europa.eu/eip/agriculture/sites/agrieip/files/8_eip_sbd_mp_biocontrol_fin }}$ $\underline{\text { al.pdf }}$

[42] Paleologos, M.F. and Sarandón, S.J. (2014) Principios de ecología de poblaciones. En Sarandón, S. J. and Flores, C.C., Eds., Agroecología: bases teóricas para el diseño y manejo de Agroecosistemas sustentables, Edulp. La Plata, Buenos Aires, Argentina, 235-258.

https://aulavirtual.agro.unlp.edu.ar/pluginfile.php/20439/mod_resource/content/1/ Capitulo\%209\%20Ecologia\%20de\%20poblaciones.pdf

[43] Pırlak, L. and Köse, M. (2009) Effects of Plant Growth Promoting Rhizobacteria on Yield and Some Fruit Properties of Strawberry. Journal of Plant Nutrition, 32, 1173-1184. https://doi.org/10.1080/01904160902943197

[44] Karakurt, H., Kotan, R., Dadaşoğlu, F., Aslantaş, R. and Şahin, F. (2011) Effects of Plant Growth Promoting Rhizobacteria on Fruit Set, Pomological and Chemical Characteristics, Color Values, and Vegetative Growth of Sour Cherry (Prunus cerasus cv. Kütahya). Turkish Journal of Biology, 35, 283-291.

http://supersol.com.tr/Files/PlantNutrition/2011Prunuscerasus.pdf 